\title{
3 Joining the international war against anarchism
}

\author{
The Dutch police and its push \\ towards transnational \\ cooperation, 1880-1914
}

\section{Beatrice de Graaf* and Wouter Klem}

\section{Introduction}

The Netherlands were much less targeted by anarchist violence than France, the Russian Empire, Spain, Italy, the United States or Germany. ${ }^{1}$ No heads of state or ministers were targeted, no casualties fell. Archival records, however, do reveal a number of reports and incidents regarding anarchist violence and visiting anarchists from abroad. The Dutch socialist leader Ferdinand Domela Nieuwenhuis pointed in his autobiography from 1910 to the spurious contacts he had with (violent) anarchists comrades from Russia or Germany. ${ }^{2}$ Not much has been written about Dutch experiences with anarchist violence. Literature on the socialist movement does mention its clashes with anarchist ideology and activists, but remains silent on the violent aspects and international contacts between fugitive dynamitards in the Netherlands and well-known socialists such as Domela Nieuwenhuis. ${ }^{3}$ Even a recent biography on Domela Nieuwenhuis only touches upon his contacts in the anarchist scene in passing, and avoids discussing his ambivalent attitude towards political violence. ${ }^{4}$ In this chapter, some first findings are presented on the struggle against anarchist violence in the Netherlands around the end of the nineteenth century.

The hypothesis is that this struggle should not merely be described as a reaction to concrete incidents and attacks, but should also be considered an expression of administrative and political agenda-setting, closely connected to the ambition of creating a modern, centralized and standardized police force, with corresponding mission statements and security ideas. This ambition was furthermore propelled by a limited number of highly influential police commissioners and public prosecutors rather than by politicians or public figures (journalists or otherwise). Dutch participation in international anti-anarchism was thus not initiated by the government or the Foreign Ministry, but by leading police officials who, as second-tier officials, displayed a remarkable energy and were present at almost all conferences and fora that were being hosted on anarchism in Europe. Anarchism was considered a veritable transnational threat: various governments struggled to find a 
response to this elusive menace. Interestingly, not governments, but secondtier officials, in this case police commissioners and prosecutors, succeeded in putting the international anarchist threat on the Dutch national agenda. Based on archival material from police records and Ministry of Justice files, this chapter demonstrates how in this case the international relations of the Netherlands were shaped from 'below' by actors from domestic services who nevertheless adopted a transnational outlooks on their work. Antianarchism can therefore be considered a field of international relations and foreign policy where professional agents from outside the direct foreign policy arena pushed the agenda, and 'overtook' the Foreign Ministry in its policy making.

\section{The rise of the global anarchist spectre}

The anarchist violence that became manifest between 1880 and 1914 is often considered the 'first wave' of modern terrorism. In numerous analogies and monographs on the history of terrorism, the Russian narodniki, French nihilists and Italian anarchists were presented as a global conspiracy of anarchist violence. ${ }^{5}$ Indeed, the extremist ideology, developed by anarchist theorists such as Peter Kropotkin, Michael Bakunin and Sergey Nechayev in the 1870s, proclaimed the overthrow of the state in favour of spontaneous and voluntarily political and economic organization, by means of violent actions, a 'propaganda of the deed' (a term coined by Paul Brousse in 1877). ${ }^{6}$

Bakunin's and Nechaev's epigones spread over the globe and unleashed, in the words of Richard Bach Jensen, a 'Decade of Regicide'. Between 1892 and 1901, 'more monarchs, presidents, and prime ministers of major world powers were assassinated than at any other time in history'. ' Other than regicide, bombs randomly went off in various cities, particularly Paris and Barcelona, but no continent remained untouched: Europe, the Middle East, North Africa, Asia, Australia, the Americas, all suffered anarchist incidents. Paris received the dubious nickname 'City of Dynamite' when the notorious anarchist Ravachol and his companions started a series of attacks in March 1892. Over a dozen bombs hit the city in the following two years. ${ }^{8}$ Barcelona and Liège in Belgium followed suit.

The perceived transnational threat of a 'Black International' conspiracy, as conveyed in the mass media of the time, was triggered by the global spread of attacks by anarchists who blew up public sites, targeted heads of state with dynamite or stabbed them to death, and threatened to unleash all kinds of destructive actions as propaganda of the deed. Between 1880 and 1914, over 750 people were wounded and around 220 people, mostly high officials and state representatives, fell victim to anarchist attacks (leaving Russia aside): amongst them Czar Alexander II (1881), King Umberto of Italy (1900), the US President William McKinley (1901), three more prime ministers, numerous regular ministers, police officials and politicians. The popular Empress Elisabeth of Austria ('Sissi') was stabbed to death by the Italian anarchist 
Luigi Lucheni in $1898 .{ }^{9}$ Some even considered the attack on the Austrian Archduke Franz Ferdinand on 28 June 1914 an anarchist attack. ${ }^{10}$ These dramatic events were further magnified in colourful newspapers, to the extent that in Paris inhabitants became terrified to frequent restaurants or attend the Opéra Garnier, and foreign tourists fled the city. ${ }^{11}$

The 'world-wide conspiracy' was a spectre invoked by the anarchists in their writings to describe their millenarian and apocalyptical utopia (or dystopia) on the one hand, and to attract new recruits to strengthen their ranks on the other. Anarchists operated new, very visible and fearsome technologies of destruction, such as dynamite and the automobile, which was not only used as a means of transport but also as a vehicle-borne improvised explosive device avant la lettre. ${ }^{12}$ Anarchist associations gratefully exploited new possibilities to communicate and to travel around the world more quickly than before. Western anarchists assisted Russian colleagues in their attempts to target the czar. A Polish anarchist took his cue to attack the czar from a newspaper report on the impending state visit of the Russian head of state to France. Russian nihilist Sergey Nechayev seized the opportunity of cheaper printing techniques for smuggling, translating and disseminating his Revolutionary Catechism abroad. ${ }^{13}$ His anarchist colleague Bakunin issued his handful of disciples with four-digit membership cards, to suggest a constituency of thousands of adherents to his World Revolutionary Alliance. And the French League of Nihilists disseminated a leaflet in 1881, in which it threatened to poison hundreds of bourgeois families by dispersing toxins in the Paris water supply. ${ }^{14}$

Such propaganda was symbolic of a new, late nineteenth-century discourse on (in)security and chaos. A new dispositive of security and governance emerged, brought into existence by, amongst others, new technological inventions and adaptions that were appropriated by the anarchists and their opponents alike. Indeed, police and security agencies quickly seized on the projected spectre of the anarchist threat and helped each other to reinforce this transnational perception. Disparate incidents and attacks were framed as a homogeneous and solid threat, to 'a grand plan to destroy Western civilization and obliterate all the monarchs and ruling heads of state and government in Europe and the Americas (if not the entire globe) ${ }^{15}{ }^{15}$ Anarchist violence was linked to larger social problems of (moral) decay and disorder and used to discredit socialist opposition at home. Moreover, the incessant wave of attacks in the 1890s was appropriated to mobilize support for the already ongoing but haphazard expansion and professionalization of police and security forces. Fear for chaos and socialism went hand in glove with an (over)reliance on and faith in technological and managerial progress and engineering. Since anarchism was framed as a global conspiracy, and a conspiracy is by its nature progressive and exponential, an increasingly dark number of participants was suggested. In this way journals, politicians and police commissioners alike attributed to the anarchists a global reach and an end goal (e.g. world power). Against this projected threat, metastasizing 
security measures and efforts were easily legitimized. ${ }^{16}$ Anarchists might have dealt the first blow, but police and security forces soon took over, especially those operating without democratic or legal constraints, such as the czarist security agency, the Okhrana. Their activities mirrored their threat perceptions. ${ }^{17}$

\section{The anarchist spill-over to the Netherlands}

Major anarchist attacks did not take place in the Netherlands (a few attempts were thwarted) and contrary to countries like Germany, France or Belgium, civil rights were not curtailed substantially. Freedoms of press, opinion and association were not seriously restricted, non-violent anarchists were not arrested or persecuted. In short, similar radicalization processes (reinforced by prison sentences, harsh sentences and public beatings by the police) to those unfolding in neighbouring countries did not take root in the Netherlands. Notwithstanding the lack of 'real' explosions, the threat was perceived and discussed in the media. In the national police magazine and in the newspapers, talk about discovered ploys and hoaxes abounded. To better understand the salience of the global anarchist threat as understood by contemporaries in the Netherlands, it is useful to realize that the 'Decade of regicide' took place in a formative period of industrialization, modernization and an increased intensity in communication technologies. Due to the rise of financial markets and the diamond industry, cities like Amsterdam and Rotterdam experienced an economic high after 1871, followed by a corresponding upsurge of urban security and criminality problems. Public disturbances and riots increased, thus putting issues of public order and security high on the local and national agendas, advanced by political parties that were founded around that same period. ${ }^{18}$

Regarding these security concerns, not the marginal anarchists, but the increasingly organized socialists represented the largest threat to the established order. ${ }^{19}$ Riots and revolts, such as the Amsterdam 'Eel Revolt' of 1886, where twenty-six people died after the police tried to suppress a public event, demonstrated that local authorities had to deal with new kinds of challenges and tensions. ${ }^{20}$ Police reports spoke of 'red flags' and subversive socialists roaming the streets. ${ }^{21}$ Nuances between anarchism and socialism, violent or non-violent types, domestic or international events were not always neatly identified. Moreover, connections were drawn between socialists in the Netherlands and explosive events abroad. In 1887, a new article was added to the Constitution, allowing the king to impose martial law and to declare the state of emergency 'in order to maintain external and international security'. Civil government would be suspended and military rule would be deployed instead, allowing the army to intervene on the king's command. ${ }^{22}$ This constitutional amendment legalized already existing practices of local army interventions at any mayor's request, thereby normalizing and standardizing this instrument of force. In March 1888, it was deployed against 
worker strikes in the northern parts of the country, in the Frisian and Groninger turf areas, after the Social-Democratic League (Sociaal-Democratische Bond, SDB) had incited the poorly paid workers to riot. Ferdinand Domela Nieuwenhuis, the SDB's notorious leader, was elected to Parliament only a few months later. Fear of socialist revolts and violent class struggles subsequently increased. ${ }^{23}$

In 1885, when violent outbursts were still the exception, Parliament had felt it necessary to prohibit transport and stockpiling explosives 'with malicious intent' per Royal Decree. ${ }^{24}$ And indeed, on 5 December 1888, on the occasion of the Dutch national celebration of Saint Nicholas, the mayor, police commander and public prosecutor of Amsterdam did receive 'hellish machines' - explosive devices, intended to blow up after unwrapping them. The true content of the surprise packages was, however, detected before they exploded. But browsing through the police and Justice archives it becomes clear that anarchist violence was considered a serious threat in those years. Police commissioners expressed their worries about socialist meetings that were usurped by anarchists, or that were misused to mobilize workers to riot. They reported on 'strangers' within their area, purportedly preparing all kinds of subversive activities. Generally, local police officers would take care of such threats on their own, together with the mayor and the local authorities. The Ministry of Justice would only be alerted in case of an urgent persecutory relevance. However, according to local and regional police commissioners and public prosecutors, anarchism was now reaching a stage of national urgency. ${ }^{25}$

Interestingly enough, compared to surrounding countries where bombs exploded and caused casualties, a moral panic and public scare did not occur. In the Netherlands, newspapers did report on anarchist attacks abroad, but (contrary to the colourful and apocalyptic pictures, paintings and dramatic stories presented to audiences in France, Germany or Spain) they did not display pictures, and wrote about the attacks in a rather curt fashion. To be sure, they capitalized on the news. After a series of anarchist bomb attacks in Paris in spring 1892, the Catholic Tilburgsche Courant lamented that it was 'nowadays no longer possible to grab a newspaper, without being dazed by the anarchists' brutality, who cold-bloodedly attacked people and property alike. In France, Belgium, Italy, Germany, Russia, Spain and America, such violence occurs time and again'. 'Read and tremble', the Rotterdamsch Nieuwsblad continued the story on the Paris attack. ${ }^{26}$

Even more drama was staged in the newspapers after the attacks on Elisabeth of Austria, a couple of years later, in 1898, and on President McKinley of the US in 1901. The Algemeen Handelsblad for example juxtaposed Sissi's beauty with the meanness of her killer: 'That charming and wonderful queen was cowardly killed by one of the West's thugs, a murderer, driven by envy and lower instincts. ${ }^{27}$ However, newspapers such as the Algemeen Handelsblad, Rotterdamsch Nieuwsblad and Het Nieuws van den Dag (the most influential ones after the abolition of the 
'dagbladzegel', or 'taxes on knowledge' in 1869), ${ }^{28}$ did not issue more than a few dramatic and judgemental lines immediately after the attacks. And although journalists incidentally called the Dutch government to arms, ${ }^{29}$ politicians and parliamentary representatives did not take up the challenge or turn it into a political campaign. According to Bart Fraanje, public scare or a media outrage did not occur, and reporting usually dried up a few days after an attack took place. ${ }^{30}$ This was probably caused by the fact that major attacks in the Netherlands did not take place.

The dispositive of the global conspiracy was less predominant in the mainstream Dutch media than it was in the specialized police journal, De Politiegids, that was set up in 1886, modelled on the British Police Guide. ${ }^{31}$ As official mouthpiece of the Dutch police union, the journal catered to hardcore police interests, argued for better equipment and advocated the implementation of modern technologies. This well-read journal - distributed to all local police stations, mayors, courts and magistrates ${ }^{32}-$ clearly did give $^{2}$ rise to prognostic claims (what should be done), calls to arms, and demands for substantial changes in administrative and political security practices. De Politiegids, moreover, openly condemned the anarchist threat as a black conspiracy of anarchist perpetrators who 'lacked a homeland', but tried to find sympathizers in all countries, whether 'thoroughbred or in potential'. De Politiegids also pointed to a potential anarchist constituency in the Netherlands, where 'the violent school from which the Ravachols ... originated [knew] many students as well'. ${ }^{33}$ The journal also expanded the threat dispositive, and turned it into a subversion of the overall public and moral order: 'And our country? ... Then a number of shocking attacks against public morality occurred. How different they might be, they seem to be connected by one single thread', the revolt against authority as such. ${ }^{34}$

Indeed, in 1894, imagination and reality met. In this year, a fugitive anarchist, responsible for a series of attacks in Belgium, was reported to have fled to the Netherlands, agitating the Dutch judicial system, only later to be identified as a Russian agent provocateur. His veritable Romanesque story has been told before, ${ }^{35}$ but a short summary is indispensable to better grasp the flight of Dutch anti-anarchist efforts thereafter. On 28 April, in the mining town of Liège, in Belgium, where recent mine accidents had fuelled unrest amongst the coal workers, a heavy bomb blew up the Saint Jacob Church in the city centre, followed by another heavy explosion five days later. The perpetrators were caught within days, only for the police to discover that they had been lured and paid by a stranger, who had moved into town a few months earlier and who travelled under the name Baron Ernest von Ungern-Sternberg. ${ }^{36}$ Von Ungern, however, managed to escape to the Netherlands, very conveniently leaving a note in his hotel room suggesting a transnational conspiracy involving eight Germans, two Dutchmen and two Belgians who allegedly had assisted him in his activities. ${ }^{37} \mathrm{On}$ 31 May, the prosecutor of Den Bosch, Theodore Serraris, notified the Minister of Justice, Willem van der Kaay, that the suspected perpetrator of 
an anarchist attack, one 'Ungern von Sternberg' had fled to Maastricht and had 'repeatedly met with the notorious and very dangerous socialist Vliegen, publisher and printer of De Volkstribuun [people's tribune]', a socialist magazine. ${ }^{38}$ Willem Vliegen was a well-known propagandist and typographer in Maastricht and would become co-founder of the Dutch Social-Democratic Party (SDAP) later in August that year. Serraris received permission to put Vliegen under surveillance and to interrogate him and his socialist comrades. ${ }^{39}$

In the meantime, Von Ungern-Sternberg had found refuge at the Russian consulate. In fact, the fake baronet was an agent of the Russian secret police, the Okhrana, named Cyprien Jagolkovsky. He worked under the instructions of his superior Pjotr Rachkovsky, who operated from the Russian embassy in Paris and had organized a series of anarchist attacks in Western capitals to reinforce suspicions of an international anarchist conspiracy. Commissioned by the Okhrana, Jagolkovsky had convinced a number of European anarchists to commit attacks, with the Liège bombings as one of the most successful operations..$^{40}$ The exact details of the Okhrana plot were not clear at that time, although in January 1895, during the trial against Von Ungern-Sternberg's Belgian accomplices, vague rumours regarding a possible sting operation surfaced. ${ }^{41}$

The affair prompted the authorities to take anarchism seriously, both as a domestic consideration and a transnational imperative. Given the transnational spread of anarchism, the Dutch judicial authorities were not only or even primarily worried about any imminent danger of anarchist bombings in the Netherlands, but they were rather more concerned that their country would become a safe haven for fugitive terrorists from abroad. Secondly, Serraris and his fellow prosecutors saw an opportunity to finally lash out against the socialist movement, something they had wanted to do for a long time. That is why Vliegen and several other socialists were put under immediate surveillance. Prosecutors travelled between Maastricht, Liège, Brussels and Amsterdam, harassing their socialist suspects. ${ }^{42}$

Moreover, for these prosecutors, the Von Ungern-case was a welcome opportunity to lobby for more security measures and to convince the Minister of Justice of the purported anarchist threat. Not only the southern provinces reported vulnerabilities. In May 1894, the prosecutor of The Hague wrote the Minister of Justice about the retrieval of a recipe for the making of a nitro-glycerine bomb in May 1894, via a 'secret informer' within anarchist circles. ${ }^{43}$ Another prosecutor informed the minister about a box with dynamite, located in a train wagon coming in from Germany. ${ }^{44}$ Both findings proved harmless (the recipe did not work and the purported dynamite turned out to be a hoax $),{ }^{45}$ but for the prosecutors, they underscored the concrete nature of the threat. After the Italian anarchist Sante Caserio stabbed French President Sadi Carnot to death in Lyon, on 28 June 1894 the Ministry of Justice did indeed send out a missive to various prosecutors, informing them about a heightened risk of dynamite attacks had spread to the Netherlands 
as well. ${ }^{46}$ And, urged on as usual by Serraris, the Ministers of Justice and War also decided to order the draft of a manual 'to deal with hellish machines' in July $1894 .{ }^{47}$

This episode spilled over into the next year, 1895, when Queen Regent Emma von Waldeck and Pyrmont took her daughter, Crown Princess Wilhelmina, on a number of high-profile city visits to warm the restless and rioting population of the southern, predominantly Catholic parts of the country towards the (Protestant) House of Orange. With the murder of the French president in 1894 in mind, the zealous prosecutor from the south, Theodore Serraris, was wary of anarchist attacks, a fear worsened by the steady influx of anarchist fugitives from France who were on the run from the increasingly repressive measures in their home country. ${ }^{48}$ In May 1895, the Regent Emma and 14-year-old Princess Wilhelmina embarked on their first railway trip. The tour induced a number of new security arrangements, most notably a special security escort, intended to deter and to fend off socialists and anarchists. ${ }^{49}$ In Den Bosch, the mayor summoned plain-clothes detectives to patrol as journalists amongst the onlookers. ${ }^{50}$ Prosecutor Serraris tried to sack socialist railway employees in advance and raided socialist headquarters once again. Soon afterwards, Vliegen's printing company went up in flames, under suspicious circumstances. ${ }^{51}$ On a central level, the Minister of Justice asked for Prussian and Belgian cooperation in organizing a seamless surveillance on itinerant anarchist activists. Two Prussian and four Belgian secret agents were added to the team of Dutch investigating officers during this royal summer. ${ }^{52}$

These punctual measures surrounding the royal tour aside, the Dutch Minister of Justice remained reluctant to adopt new laws similar to the French, Russian or Prussian ones. He kept to his liberal position and fended off both his prosecutor Serraris and the Prussian envoy, who demanded stricter laws. According to the Prussian police, Dutch socialists and anarchists, who enjoyed free rein in publishing and disseminating their riotous ideas in the Netherlands also ventured into neighbouring Germany, thereby causing 'the security of ... friendly states to be endangered, and public order and quiet to be disrupted'. Minister Van der Kaay, however, was not susceptible to this demand for solidarity. Socialist 'dissemination has taken place freely for years now, by virtue of the constitutionally guaranteed freedom of speech, for anyone to ventilate his ideas'. The minister did not see any merit in 'cultivating martyrs' or 'sowing the seed of resentment' amongst the social-democrats, thereby 'nourishing that party'.

Experience taught us the efficacy of this line of conduct, because it stands without doubt that social-democrat turmoils in the Netherlands have not merely waned both in numbers and relevance for some years now, but the influence of their leaders on the population has decreased considerably as well, and interest in the movement itself is gradually declining. ${ }^{53}$ 
According to the minister, incidental measures were one thing, but ordering large-scale repressive laws something else altogether. He was, moreover, not inclined to respond to pressure from abroad. As Van der Kaay pointed out to Serraris, 'each case has to be judged on its own' ${ }^{54}$ Compared with Germany, socialism was in retreat in the Netherlands, thus ignoring them and not providing them with more ammunition seemed the most effective approach. Van der Kaay saw his strategy furthermore backed up by British experiences, where the police claimed an actual decrease of socialist and anarchist meetings resulting from the lack of open repression..$^{55}$ No War on Anarchism was instigated, as far as the minister was concerned. Other officials working for his department, most notably some police commissioners, did not take the threat so lightly or let this opportunity for expanding their competences slip so easily.

\section{Transnational friends}

Compared with other European countries the expansion of the police and security apparatus was kept in rein, partly by the lack of successful attacks, partly by other considerations of a more liberal, economical or even historical nature. Dutch representatives and commentators reminded their audiences for example of the consequences of a repressive haute police, when the Dutch suffered 'under Napoleon's iron rod and multiple spies'. ${ }^{56}$ Until late in the nineteenth century, the overriding ideas on police activities pertained to a rather passive and reactive strategy of maintaining public order and peace. The socialist movement and the industrial proletariat were less developed and counted fewer members than elsewhere in Europe. Central security agencies similar to those in the Austrian empire, Prussia or France did not exist in the Netherlands.

Exactly this lack of urgency at a central level increasingly nagged at public prosecutors and their police commissioners placed in sites of increased transnational exchange and traffic. As we have seen, Den Bosch's prosecutor Serraris saw himself increasingly confronted with anarchists from abroad, who were extradited by France, or had 'voluntarily' left the country in search for a safe haven in the north. In Rotterdam, the new head of police, Commissioner Willem Voormolen, registered an increase of anarchists in the city's international harbour, originating from all over the globe. 'As the number of steamships, which arrive in Rotterdam, increases, so does the surveillance over foreigners and immigrants and it must be prevented that people, troublemakers that one could not get rid of ... step ashore', he reported to his mayor. His biggest fear, relating to foreign troublemakers or potential fugitive anarchists, was that their use of fake names made identification virtually impossible and that they could roam the country undetected..$^{57}$ At that time, the police still consisted of local and regional constabularies, with the local mayors as corps chief. Serraris and Voormolen therefore felt it was high time that the Ministry made a move on central level. 
In tandem, they started to lobby the central Ministry to adopt three new instruments, central to a professionalization of their respective divisions in the law and order department: Serraris and fellow prosecutors advocated stricter press controls, ${ }^{58}$ while Voormolen, together with public prosecutor Kist from Amsterdam, urged the minister to arrange for new detective facilities, making use of identification and registration technologies. ${ }^{59}$ The Rotterdam commissioner furthermore advocated stronger transnational cooperation in the struggle against anarchism (extraditions, information exchange).

The incidental reporting and extraditing of suspect foreigners, vagrants, and/or activists without a licence should be replaced by a centralized

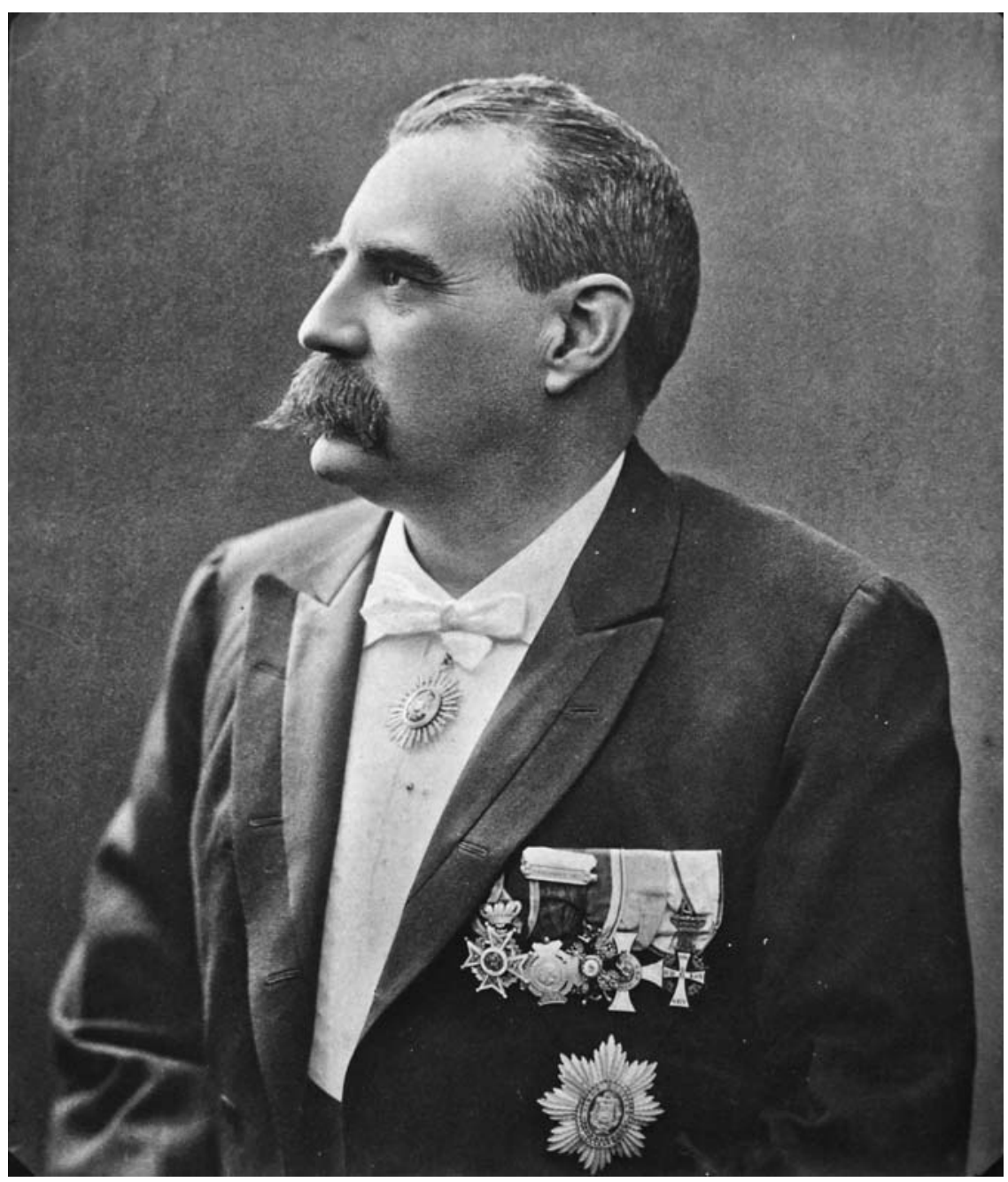

Figure 3.1 Willem Voormolen, head of police, Rotterdam, 1893-1908 (Stadsarchief Rotterdam) 
monitoring approach, Voormolen argued. In fact, he had his eyes on a system of so-called Bertillonage, developed around 1882 by the French police prefect Alphonse Bertillon. ${ }^{60}$ By means of registering bodily traits and measures, portraits parlés could be assembled based on a system of numbers and codes. Although it had the advantage that it systematized crime-scene photography and developed a standardized identification system based on physical measurements, it was a highly tiresome and unstable procedure to securely and unambiguously make and register these measures. Still, the anthropometrical data could be transmitted on short notice to police forces abroad, in order to identify and arrest fugitive criminals or suspects - which was something of a revolution, at least on paper, since most of the suspects still managed to keep their identity hidden until that time, or were able to escape with forged identity cards. ${ }^{61} \mathrm{New}$ shipping lines and railway connections furthermore enabled photographs to be dispatched more quickly as well. ${ }^{62}$

These new technologies, which included international warrant posters, not only served to identify suspects or to improve prosecution, but they also acted as markers of prestige for modern national security forces. Within the context of increasing bilateral and transnational cooperation, these modern applications were perceived as of vital importance for the image of the supposedly - most advanced and professionalized forces. Hence, the young and ambitious Voormolen (he was 35 years old, when appointed commissioner in 1893) was so adamant in pressing his minister to tune into the new scientific insights and international developments that had already been adopted in France, the United Kingdom, and were being considered in Germany as well. ${ }^{63}$ In February 1896, Voormolen reached his goal when, per Royal Decree, the Dutch police and judicial forces decided to implement the Bertillon system. ${ }^{64}$ Both Bertillon himself and Voormolen received a royal decoration. ${ }^{65}$

A year later, the minister had some doubts about the effectiveness of the system and had to admit, in response to parliamentary questions on the matter, that positive results were not obvious. He did, however, stress the possibility that the system's introduction would deter foreign anarchists from seeking asylum in the Netherlands. The fact that few incidents of 'contested identity and subsequent recognition' had occurred in the previous months might just be the effect of the implementation of the system. The minister indicated that where before 'so-called international criminals' could have dwelled in the Netherlands safely under a false name, 'they could no longer now find refuge in our country, after the introduction of the system hither'. And in case of apprehension, these criminals now knew that hiding their identities had become pointless. ${ }^{66}$

That same year, in 1896, the liberal member of Parliament Baron Van der Feltz obtained a parliamentary majority for the implementation of a plainclothes detective force, a 'Secret Police Force' (korps geheime politie); for criminal investigators and detectives, a higher level of education became obligatory, and in March 1897, the first federal police investigators were 
appointed: trained and tasked to carry out professional prosecution and investigation duties, equipped with special investigative means, and embedded within the Office of the Public Prosecution. ${ }^{67}$ As a result of these measures, prosecution of socialists and anarchists tripled. ${ }^{68}$ The Dutch were at least keeping up appearances with neighbouring countries and police forces, and paying tribute to the struggle against anarchism.

The third desire, to participate more strongly and more centrally in the international struggle against anarchism, translated into the appointment of more police experts and the implementation of new technologies. For Voormolen, the adoption of the Bertillon system as such would remain a symbolic measure at most, if this decision did not find an echo in a more structural centralization and internationalization of police activities in the field of anti-anarchism and the fight against international (organized) crime as such. A year after his appointment in Rotterdam Voormolen had already made several trips to France and Germany in 1894. Fluent in German, French and English, and proficient in Italian, and well-travelled (he had a history in the navy, and had fought pirates in the Moluccas), ${ }^{69}$ he managed to build an impressive network of leading police officials of the time. In Paris, he met the Chef du Service de Sureté, Armand Cochefert, in Hamburg the famous Gustave Roscher, in London the internationally renowned William Melville, head of Scotland Yard's anti-anarchist Special Branch, and in the Berlin the controversial police reformist, Criminal Inspector Leopold Meerscheidt-Hüllessem. Through these contacts, and supported by the Ministry of Justice's lobbying, ${ }^{70}$ Voormolen managed to get himself invited to the 'Berlin Conference on the discussion of the introduction of Bertillon's system in the states of the German Empire'. With his well-known expertise and experience in the new technologies of registration and identification, Berlin police president Von Windheim personally favoured Voormolen's attendance. ${ }^{71}$ For Voormolen, this was an exquisite opportunity for networking and benchmarking purposes.

The Conference convened in June 1897 and brought together representatives from the German Empire, Austria-Hungary, Rumania - and Commissioner Voormolen. Technicians demonstrated the latest novelties in photography, commissioners exchanged their knowledge and experience in classification and measuring techniques. But most importantly, the commissioners expressed the desire to be part of a shared transnational community - to be materialized in regular meetings and exchanges. ${ }^{72}$ Against the backdrop of the rising threat of international criminality, they felt it necessary to organize events to discuss and agree upon transnational surveillance operations against anarchists and other criminals, and upon a general convergence in standards, technologies and communication - for which Voormolen was invited to participate on behalf of the Netherlands. Hence, Voormolen brought back a personal network of 'chers amis' stretching from the German Empire to Rumania. Capitalizing on these new relations, Voormolen returned the favours and invited his international colleagues to the Netherlands to speak at a newly established network of Dutch police commissioners, 
inaugurated in March 1898 at the luxury Hotel Pays Bas in Utrecht. ${ }^{73}$ Naturally, Voormolen was named president of this 'Brotherhood of Chief Commissioners and Commissioners', and his friend Roscher from Hamburg and Dutch former Minister of Justice Hendrik Jan Smidt were installed as honorary members. ${ }^{74}$

In the midst of these transnational police overtures, on 10 September 1898, an Italian anarchist, Luigi Lucheni, lashed out with a sharpened file and stabbed Empress Elisabeth of Austria to death. ${ }^{75}$ The shock and outrage in Vienna was unheard of, spilled over to the other countries of the West, and did not leave Dutch society untouched either; richly detailed reports on the assassination were distributed in the media. ${ }^{76}$ One day later, on 11 September, the London-based newspaper Weekly Dispatch disclosed rumours of an assassination plot involving Luigi Lucheni, another Italian anarchist Giuseppe Ciancabilla and a Giovanni Galiani, who had been conspiring to assassinate the Dutch Queen Wilhelmina during her coronation on 31 August 1898, but were thwarted by German police spy Eugen Werner, alias Sickering. Allegedly, Scotland Yard's William Melville had got wind of the plot. Le Soir and the socialist journal Vorwärts reiterated the rumours a few days later. ${ }^{77}$ On 13 September, Voormolen himself received a letter warning him of the purported threat against Wilhelmina by three Italians. ${ }^{78}$ Three Italian citizens had indeed arrived in Rotterdam, as Voormolen's detectives confirmed, but the next morning they had left already, to Brussels and to Frankfurt. Although Wilhelmina refused any security detail since 1895, Voormolen and the detectives from the newly created Secret Police Force kept her under close watch, and tailed the Italians until they had safely left the country. ${ }^{79}$ The detectives, however, were ordered to patrol the woods surrounding the palace in Apeldoorn for months thereafter, riding around on their specially purchased bicycles. ${ }^{80}$

During that same hot summer, the Berlin Polizeipräsidium had started creating a so-called 'Anarchisten-Album', a collection of photographs of known anarchists from around the globe, famous and more inconspicuous ones alike. The album contained pictures of already familiar anarchists, such as Lucheni, Emma Goldman, but also the image of Ferdinand Domela Nieuwenhuis. The album was not a German invention; commissioners in Paris, London and Rotterdam already had done the same. ${ }^{81}$ In fact, Voormolen himself had collected over 1,700 registration cards of anarchists of various backgrounds, accompanied by a collection of more than 500 photographs. Voormolen informed the Ministry of Justice that data on any suspect Italian could be compared and matched with his dataset, and that he, moreover, would set out to obtain a copy of the Berlin album. ${ }^{82}$ He managed to lay hands on one via his friend Hüllesem that same month, but found out that his collection by far exceeded the Prussian one. He therefore proudly presented Hüllessem with 186 additional pictures (and received 150 new ones himself in return). ${ }^{83}$ These collections, used to compare and exchange the body of (biometrical) knowledge on known and lesser known (fugitive) 
anarchists, served to facilitate transnational surveillance, but also symbolized the dynamics of police officials vying for budget and recognition from their ministers, and from each other.

Thus equipped with anarchist data sets, police forces in Rotterdam, London, Paris, Berlin and Bern cooperated and corresponded with each other directly or via embassies to hunt Lucheni's fugitive comrades before they struck again. ${ }^{84}$ Ciancabilla was spotted in Switzerland in October, absconded and, together with Giovanni Galiani, finally relocated to Paterson, New Jersey, in the United States. There, they joined the lively anarchist community around Malatesta and lived on as spuriously and truculently as before. ${ }^{85}$ Thus equipped with transnational friends, ties and ongoing exchanges on data regarding fugitive anarchists, Voormolen could further propel the Dutch contribution to the institutionalization of the transnational struggle against anarchism.

\section{The Anti-Anarchist Convention}

Voormolen's efforts in modernizing, professionalizing and internationalizing the Dutch police forces were perfectly in tune with the grand schemes developed by the new Justice Minister, who took office in 1897, the progressive liberal Cort van der Linden. Anarchism was of course not the main driver behind these processes, but the threat of 'foreign enemies against the state and society' proved an exceptional vehicle to propel these efforts and convince Parliament and society alike of its necessity. Under Van der Kaay, the Ministry of Justice had diligently cooperated with Belgian and Prussian authorities to extradite suspicious individuals, or put them under surveillance. However, far more than his predecessor, Cort van der Linden was convinced of the need to implement structural measures to counter the anarchist threat and keep a close watch on 'dangerous foreigners'. This conviction was compounded by his intention to completely overhaul the police organization as such. ${ }^{86}$ To develop a blueprint for a Dutch police modernization, he appointed a committee in the autumn of 1898, a few weeks after the killing of Empress Elisabeth by the Italian anarchist Luigi Lucheni. The committee was chaired by Herman Kist, the prosecutor of Amsterdam, and included Voormolen from Rotterdam and Franken, the head of police in Amsterdam. ${ }^{87}$

When, encouraged by the German and Austrian governments, the Italian government staged an 'International Conference for the Defence of Society against the Anarchists' in Rome, that lasted from 24 November until 21 December 1898, Cort van der Linden dispatched Kist to represent the Netherlands. Guarded by an intense military presence, experienced diplomats and high-ranking police officials from all European countries convened to discuss the looming threat of anarchism and the ways and means to counter it. ${ }^{88}$ 'Metternich's Holy Alliance' resurrected 'from the Death', jibed the socialist journal Vorwärts ${ }^{89}$ Customized and standardized laws against anarchism, 
defamation and anarchist glorification were floated, discussed and adopted by some countries, but not by all. Like his colleagues in other, relatively liberal and democratic countries (the UK most notably), the Dutch Minister of Justice had instructed Kist and the ambassador in Italy, Bernard Westenberg (who together made up the delegation of the Netherlands), not to vote for special anti-anarchist legislation ${ }^{90}$ - wary as he was of political machinations and manipulations from more authoritarian countries. Regarding the contentious issue of an anarchism definition, the Minister declared he was in favour of 'an international plan to put surveillance over anarchists', without having a desire to take a lead in such a plan. The delegates were instructed only to agree upon definitions of plans after a majority of countries had granted their support. ${ }^{91}$

Accordingly, Kist partook in two committees on legislative and administrative anti-anarchist measures, but refrained from openly supporting such initiatives. Interestingly, the conveners were mostly police officials. Civilians were not invited to these key platforms and played a minor role. Westenberg's activities, for example, were limited to attending the plenary sessions and signing the final protocol..$^{92}$ Not surprisingly, the German Ernst von Philipsborn, a Geheimrat of the Prussian Minister of the Interior, gave the final battle cry. Fully in line with the Berlin Conference that took place a year before, he declared that all nations should consider it their duty to defend their common interests against 'all elements threatening security', and that it was therefore high time to establish central police authorities in each country designated to correspond with their foreign counterparts on monitoring the transnational anarchist threat. Furthermore, these police authorities should work together either to influence national legislation or find other ways to identify, prosecute and expel fugitive anarchists to their mother countries - of course after due notice by the proper authorities, e.g. the border police. ${ }^{93}$ When the Chief Commissioner of Stockholm, Semmy Rubenson, backed by Britain, questioned such a blanket approach and instead proposed to focus on acts rather than on vague threats or ideological utterances, he was rebuffed by his German hosts. ${ }^{94}$ Russia's and France's delegates decided to support the German declaration, but, tied by his minister's instructions, Kist withheld his support. ${ }^{95}$ In order not to tear the fabric of this emergent transnational police cooperation Kist did intervene with a tactical solution. He submitted an amendment enabling expulsion only upon the condition that neighbouring countries would be informed and would agree upon the measure. ${ }^{96}$

On a more technical level, and in a confidential session, former Scotland Yard director and MP Howard Vincent chaired an international exchange on best practices in extraditing unwanted 'aliens', identification and registration methods, albums and data sets. Here, Kist operated less conspicuously - and went beyond his mandate in the process. Since expulsion of extremists on ideological grounds was not possible according to the Dutch Penal Code, Kist suggested to adopt the less judicially charged term 'éloignement'. 
This would merely 'entail' the removal from Dutch soil of foreigners lacking regular papers or means of livelihood. The question of political justice loomed large, and a rift opened up between countries in favour of penalizing anarchism as an ideological category versus those who remained attached to only certain acts. ${ }^{97}$ Nevertheless, all attending countries agreed to establish a central police desk or authority in their respective countries through which monthly reports on expelled persons and the reasons for their expulsion would be shared. ${ }^{98}$ Irrespective of ideological stances, a transnational cooperation on policing anarchists was born; the first international 'black listing' technologies were institutionally baptized.

In the Netherlands, Cort van der Linden was happy to establish a covenant with his colleague at the Foreign Ministry, Willem de Beaufort, to create such a central authority within his department. For Voormolen, this meant that foreign authorities, including police commissioners and ambassadors, would now directly dispatch their intelligence to the Minister of Justice, rather than to his office in Rotterdam. As a result, Voormolen's contact with Von Windheim came to an end, but he remained at the core of the Dutch anti-anarchism activities through his membership of the Committee-Kist. Although the Conference's Final Act (signed by the Dutch representatives as well) was non-binding, Voormolen, Kist and Franken did not hesitate to copy-paste the Conference's formal definitions and publicly and officially proclaim anarchism - defined as 'the destruction through violent means of all social organisation' - a danger to public order. The threat of anarchism was explicitly used as argument in favour of restructuring the national police organization. The Committee-Kist advised the Dutch government that 'out of concern for society, regarding anarchist movements and attacks, that not only threaten the state but also target society as a whole', a nationalized and centralized police force was highly necessary. ${ }^{99}$ Only through such a centralized force, on par with foreign services, could the growing international threat be countered. ${ }^{100}$ Even although the Kist recommendations on largescale police reforms were put on hold, anti-anarchist and alarmist language began to infuse the parliamentary political discourse - and it influenced internal reforms of the police and judicial apparatus.

In a similar vein, the Pierson government (1897-1901), known for its engagement to advance social justice, ventured to introduce large-scale security measures. ${ }^{101}$ The Dutch socialist leader Domela Nieuwenhuis condemned the subsequent bill as a reactionary anti-anarchist law. ${ }^{102}$ In the end, Cort was denied the dubious honour of having furnished Dutch legal history with the first anti-terrorism law ever. His Catholic successor, Jan Loeff, retracted this by-far-too-expansive governmental bill in September 1901 without much ado. ${ }^{103}$ Some parts of it, however, were implemented after all: a central desk within the Ministry of Justice was created, for enabling the collection and exchange within the country, and with foreign colleagues, of data on anarchists and their attacks. Moreover, a network for transnational police cooperation was now officially sanctioned and established, with 
Voormolen in the lead. In 1906, Voormolen managed to convince the Minister of Justice to replace the Bertillon system with the novel technology of dactyloscopy he had studied in Dresden. ${ }^{104}$ Moreover, he kept sending and returning his anarchist photographs, playing quartet with his colleagues abroad.

In 1904 the socialist politician Pieter Jelles Troelstra complained that the Amsterdam police force had freely issued its data on an anarchist conference and its international attendants in the Netherlands to their colleagues from the Okhrana - under the pretext of the international fight against violent anarchism. ${ }^{105}$ But no law prohibited them from engaging in this exchange. On the contrary, Dutch police commissioners continued sharing intelligence with colleagues from neighbouring countries - either on an informal plane, or officially, upon request via the Foreign Ministry. The Chief of the Paris branch of the Okhrana himself, Leonid Rataev, came to Amsterdam on the eve of the international anarchist conference. He contributed to the surveillance of his travelling subjects in person, took photographs and copied hotel registers. The Amsterdam police politely assisted and watched over him. ${ }^{106}$ The central police authority duly kept compiling its monthly reports, but no violent anarchist activities were listed until 1914 (when our research ends). ${ }^{107}$ Notwithstanding this lack of 'real' attacks taking place in the Netherlands, the country - through Voormolen's incessant activities and contacts - had become a full member of the transnational network of anti-anarchist forces.

\section{Conclusion}

Although no bomb exploded and no anarchist attack succeeded in the Netherlands, rumours and reports of violent attacks in other countries were spread and disseminated in official sources, police records and through the media. Concrete evidence regarding fugitive anarchists from elsewhere finding refuge or passing through the country circulated widely within the police and judicial corridors. Contrary to the German Empire, France or czarist Russia, the Netherlands lacked a centralized and authoritarian regime-wielding power, and in the end no special anti-anarchist law was implemented. Interestingly, both the perception of a transnational threat and the measures to counter such a threat were put on the agenda not by the Dutch government but by metropolitan police commissioners and prosecutors from the border regions. Informed by their transnational networks, and invigorated by their drive for modernization and professionalization, they campaigned to convince the Dutch government to participate in the international war on anarchism.

Until 1894, this process of bottom-up securitization unfolded behind the scenes, within the regional police and judicial departments. At this stage, expansion of security measures and infringements on constitutional liberties were inhibited by judicial and administrative constraints at the central level. 
Up until 1897, subsequent ministers were not prepared to support political prosecution practices - mostly because of the high costs and the required additional budget involved, but also because members of the Dutch political caste, especially liberal Minister Van der Kaay, did not feel the need to align with authoritarian regimes abroad in dealing with political violence. Within the Dutch system, there was no place for deploying agents provocateurs as the Okhrana did. Nor was there enough political support for the implementation of a 'thought police', total censorship or ideologically motivated prosecution.

However, from 1894 onwards news about attacks abroad, in France, Germany and Russia, gained traction, reaching the Dutch public through various new information and communication channels. 'Technologies of imagination' transformed the distant, imagined threat of anarchist violence into a vivid and material danger. Police commissioners assembled and disseminated wanted posters and pictures of fugitive anarchists, portraits parlés (identity cards containing anthropometric data) within the country and abroad, and assisted their foreign police colleagues when possible. Newspapers, telegraph, telephone and coffeehouse rumours contributed in this process of public dissemination and securitization of the global anarchist threats.

Commissioners such as Voormolen, assisted by prosecutor Serraris and Kist, strived to tune into a developing international police culture. Following Mathieu Deflem, Jens Jäger and Frederic Zuckerman, we could even speak of an 'evolution of a common police culture amongst the forces of European order" 108 in the 1890s, propelled by both a series of high-profile anarchist attacks and the invention of new kinds of communication and identification technologies. At the Berlin Conference in 1897, and even more substantial after the Rome Conference, this international police culture received an irreversible and intense stimulus to counter the wave of anarchist terror with similar concrete measures. ${ }^{109}$ In the Netherlands this international dispositive of the war against anarchism was embraced by Minister Cort van der Linden, who even accepted a breach within the Dutch legal culture and history by introducing bills that enabled far-reaching repression of anarchist (and socialist) utterances and activities. Urged by the ambition to raise the Dutch efforts up to international standards, to avoid the reputation of being 'benign' on both domestic and international fugitive anarchists by offering them the opportunity of a safe haven, the minister and his aides (most notably Voormolen, Kist and Serraris) attempted to converge Dutch legal and administrative measures with the programmes adopted by their colleagues abroad. In this, these professional actors were prepared to circumvent or press their governments in venturing further in the field of anti-anarchist activities than they might have intended to do.

In 1901, Cort's successor Loeff retracted the package of legal amendments to the Penal Code as being too wide-ranging and far-fetched. However, this legal recoiling set aside, substantial innovations in the field of identification and registration and administrative centralization were accepted and 
implemented. After 1898, structural surveillance and deportation of suspect foreigners, the creation of a central desk for transnational information coordination and exchange within the Ministry of Justice, and the introduction of a new force of plain-clothes detectives ushered in a new mode of security governance: one that superseded the rather laid-back and ad hoc measures applied by previous cabinets and that heralded a more internationally oriented, preventative and proactive control. In the light of transnational terrorist threats, this case study teaches us about the almost unstoppable securitizing force of professional actors in the international arena - and their success in shaping their administrative environments (and to a certain extent even reluctant ministers) to meet their transnational security demands.

\section{Notes}

* Some elements from the first half of the chapter are an expansion of the argument made in two previous articles by De Graaf: B. de Graaf, "Van "helsche machines" en Russische provocateurs: De strijd tegen het anarchisme in Nederland', Tijdschrift voor Geschiedenis 125:3 (2012) 314-331; idem, 'The Black International conspiracy as security dispositive in the Netherlands, 1880-1900', Historical Social Research 38:1 (2013) 142-165.

1 The research leading to these results has received funding from the European Research Council under the European Union's Seventh Framework Programme (FP/2007-2013) / ERC Grant Agreement n.615313.

2 F. Domela Nieuwenhuis, Van christen tot anarchist (Amsterdam 1910) 365-377.

3 J. Charité, De Sociaal-Democratische Bond als orde- en gezagsprobleem voor de overheid (1880-1888) ( $\mathrm{PhD}$ dissertation, Leiden University 1972); D. Bos, Waarachtige volksvrienden: De vroege socialistische beweging in Amsterdam 1848-1894 (Amsterdam 2001); J. Perry, De voorman: Een biografie van Willem Hubert Vliegen (Amsterdam 1994); idem, Roomsche kinine tegen roode koorts. Arbeidersbeweging en katholieke kerk in Maastricht 1880-1920 (Amsterdam 1983); W. Vliegen, De dageraad der volksbevrijding: Schetsen en tafereelen uit de socialistische beweging in Nederland, two volumes (Amsterdam 1905-1921); W. Vliegen, Die onze kracht ontwaken deed: Geschiedenis der Sociaaldemocratische Arbeiderspartij in Nederland gedurende de eerste 25 jaren van haar bestaan, three volumes (Amsterdam 1924-1938).

4 J.W. Stutje, Ferdinand Domela Nieuwenhuis: Een romantische revolutionair (Amsterdam 2012) 327-329.

5 D.C. Rapoport, 'The Four Waves of Modern Terrorism', in: A. Kurth Cronin and J. Ludes (eds), Attacking Terrorism: Elements of a Grand Strategy (Washington DC 2004) 46-73.

6 C. Bantman, The French Anarchists in London, 1880-1914: Exile and Transnationalism in the First Globalisation (Liverpool 2013) 6-7.

7 R.B. Jensen, 'Daggers, rifles, and dynamite: Anarchist terrorism in nineteenth century Europe', Terrorism and Political Violence 16:1 (2004) 116-153, 134.

8 J. Merriman, The Dynamite Club: How a Bombing in Fin-de-Siècle Paris Ignited the Age of Modern Terror (London 2009) 80-81.

9 R.B. Jensen, The Battle against Anarchist Terrorism: An International History, 1878-1934 (New York 2014) 31-36.

10 Russo-American anarchist Alexander Berkman declared in The New York Times of 29 June 1914: 'The assassination of Ferdinand was a plot of the anarchists 
and the revolutionaries ... to strike down the only man strong enough to continue the iron rule of Emperor Francis Joseph.' See: V. Dedijer, 'Sarajevo fifty years after', Foreign Affairs 42:4 (July 1964) 569-584, 577-578.

11 Merriman, The Dynamite Club, 78-86.

12 M. Davis, Buda's Wagon: A Brief History of the Car Bomb (London/New York 2007).

13 Cf. A. Butterworth, The World That Never Was: A True Story of Dreamers, Schemers, Anarchists and Secret Agents (London 2010).

14 Ibid., 62-63, 181-182.

15 R.B. Jensen, 'The international campaign against anarchist terrorism, 18801930s', Terrorism and Political Violence 21:1 (2009) 89-109, 91.

16 Z. Ivianski, 'Provocation at the center: A study in the history of counter-terror', in: D.C. Rapoport (ed.), Terrorism: Critical Concepts in Political Science, Vol. 1: The First or Anarchist Wave (London/New York 2006) 339-368, 341; Jensen, The Battle against Anarchist Terrorism, 44-45.

17 F. Zuckerman, The Tsarist Secret Police Abroad: Policing Europe in a Modernising World (New York 2003) 74.

18 P. de Rooy et al., Waakzaam in Amsterdam: Hoofdstad en politie vanaf 1275 (Amsterdam 2011) 298-321; W.M. Klem, 'Van kranten venten tot massademonstratie: De stemrechtstrijd in Den Haag van 1880 tot 1887', Jaarboek van de Geschiedkundige Vereniging Die Haghe (2014) 96-123. See also: 'Een terugblik', De Nederlandsche Politiegids, December 1888, no. 36. With thanks to Jos Smeets.

19 Charité, Sociaal-Democratische Bond; Bos, Waarachtige volksvrienden.

20 P. de Rooy, Een revolutie die voorbijging: Domela Nieuwenhuis en het Palingoproer (Bussum 1971); R. van der Wal, Of Geweld zal worden gebruikt: Militaire bijstand bij de handhaving en het herstel van de openbare orde 1840-1920 (Amsterdam 2003) 172-173; Bos, Waarachtige volksvrienden, 207-221.

21 Cf. Gemeentearchief Amsterdam (GAA), 5225, Telegrams of Bureau Section 5 to Central Bureau, 25 July 1886, 5.50 afternoon, no. 164 and idem, 7.56 afternoon, no. 148. With thanks to Bernard Bremmer.

22 R.W. van Zuijlen, Veiligheid als opdracht: Een onderzoek naar veiligheid als fundamenteel recht en als positieve verplichting van de staat in het licht van de politietaak tot strafrechtelijke rechtshandhaving (Nijmegen 2000) 66.

23 Domela Nieuwenhuis, Van christen tot anarchist, 99, 122, 132, 442. Domela Nieuwenhuis denies in his autobiography any violent behaviour on behalf of the Dutch socialists and anarchists: they were no 'dynamite men'. He discards allegations of this nature by Minister Heemskerk as 'mendacious'. He does admit, however, to his admiration for foreign anarchists as Elysée Reclus and Peter Kropotkin, whose texts he translated in 1885.

24 Royal Decree, 15 October 1885, Staatsblad, No. 187.

25 Nationaal Archief, The Hague (hereafter NL-HaNA), 2.09.05, 6486, Letter of the public prosecutor of Amsterdam to the Minister of Justice, 14 June 1894, no. 8 .

26 'Aanslagen', Tilburgsche Courant, 24 March 1892; 'Buitenland', Rotterdamsch Nieuwsblad, 29 March 1892.

27 'De Keizerin van Oostenrijk', Algemeen Handelsblad, 17 September 1898, evening edition.

28 See for example W. Visser, De Papieren Spiegel: Honderd-vijf-en-twintig jaar Algemeen Handelsblad 1828-1953 (Amsterdam 1953) 287; J. Schouwenaar, Tussen Beurs en Binnenhof: J. W. van den Biesen en de politieke journalistiek van het Handelsblad (1828-1845) (Amsterdam 1999) 13; H. Wijfjes, Journalistiek in Nederland 1850-2000: Beroep, cultuur en organisatie (Amsterdam 2014) 18, 38-39; B. Fraanje, 'Over internationale dollemannen, nietsontziende dwepers en 


\section{Beatrice de Graaf and Wouter Klem}

leprozen in de politiek: Framing van de berichtgeving over het anarchisme in Nederlandse kranten 1898-1901' (unpublished MA thesis, Utrecht University 2016) 9.

29 'Buitenlands overzicht', Algemeen Handelsblad, 1 April 1892.

30 Fraanje, 'Over internationale dollemannen', 66-69.

31 Voorwoord', De Nederlandse Politiegids, January 1886, no.1; '1886-1911', De Politiegids, January 1911, no. 301.

32 C. Fijnaut, De geschiedenis van de Nederlandse Politie: Een staatsinstelling in de maalstroom van de geschiedenis (Amsterdam 2007) 211, 306-312.

33 'Aanranding van 't Gezag', De Nederlandse Politiegids, July 1894, no. 103.

34 Ibid.

35 B. de Graaf, 'Van "helsche machines"; idem, 'The Black International'.

36 Butterworth, The World That Never Was, 338-345. Butterworth did not conduct research in the Netherlands, and does not take into account the consequences in the country. NL-HaNA, 2.09.05, 6486, Cabinet du Juge d'Instruction/ Arrondissement de Liège, 'Signalement et Portrait', Liège, 20 May 1894.

37 'Les Anarchistes de Liège', L'Express du midi, 18 January 1895.

38 NL-HaNA, 2.09.05, 6486, Letters of Serraris to the Minister of Justice, 31 May 1894 and 2 June 1894.

39 Perry, De voorman; A.A. de Jonge, Het communisme in Nederland: De geschiedenis van een politieke partij (The Hague 1972).

40 Butterworth, The World That Never Was, 342.

41 Cf. 'België', De Baanbreker, 5 January 1895, vol. 58; De Baanbreker, 26 January 1895 , vol. 61.

42 NL-HaNA, 2.09.05, 6486, no. 2, Letters of Serraris to the Minister of Justice, Den Bosch, 2 June 1894, and no. 9, 14 June 1894.

43 NL-HaNA, 2.09.05, 6486, no. 10, Exchange between the regional police and the Minister of Justice, 22 May - 13 June 1894.

44 NL-HaNA, 2.09.05, 6486, no. 25, Letter of the Amsterdam Prosecutor-General Kist to the Minister of Justice, 20 July 1894; Letter of the Public Prosecutor of Haarlem to the Minister of Justice, 27 July 1894.

45 NL-HaNA, 2.09.05, 6442, no. D36, Letter of the Minister of Justice to the Minister of War, 3 August 1894.

46 NL-HaNA, 2.09.05, 6493, no. 22, Secret letter of the Minister of Justice to the Attorneys General, The Hague, 28 June 1894.

47 NL-HaNA, 2.09.05, 6642, no. 12139, Letter of Serraris to the Minister of Justice (secret), 6 July 1894; no. 36, Minister of Justice to the Minister of War, 3 August 1894.

48 NL-HaNA, 2.09.05, 6487, Letter of Serraris to the Minister of Justice, 11 May 1895.

49 NL-HaNA, 2.09.05, 6487, no. 27, Decree, signed by the Minister of War and Her Majesty Wilhelmina, 28 February 1895; no. 3, Letter of the Minister of Justice to Serraris, 5 April 1895.

50 J. Biemans (ed.), Koninklijke bezoeken aan's - Hertogenbosch 1895-2006 (Alphen aan den Maas 2007).

51 NL-HaNA, 2.09.05, 6487, no. 9, Exchange between the Minister of Foreign Affairs and Serraris, 18 May 1895; no. 3, Exchange between the Minister of Justice and Serraris, 4 June 1895.

52 NL-HaNA, 2.09.05, 6487, no. 12, Letter of Serraris to Minister of Justice, 17 June 1895.

53 NL-HaNA, 2.09.05, 6488, no. 6, Exchange between the Minister of Justice, the Minister of Foreign Affairs and the German envoy, 18 December 1895 and 8 January 1896. 
54 HTK 1894-1895, 2.IV.13-A, State budget for the Ministry of Justice for 1895, 3.

55 Ibid.

56 'Geheime Uitgaven', I and II, De Nederlandsche Politiegids, March and April 1890 , no. 51 and 52.

57 Stadsarchief Rotterdam (hereafter SAR), 444-01, 5952, Report by Voormolen to the Mayor of Rotterdam, 11 June 1895, 27-28.

58 NL-HaNA, 2.09.05, 6487, no. 18, Letter of Serraris to the Minister of Justice (with notes from the Minister), 24 January 1895.

59 NL-HaNA, 2.09.05, 6486, no. 7, Exchange between the Minister of Justice and Attorneys General Kist (Amsterdam) and Serraris, 26-30 August 1894.

60 SAR, 444-01, 5952, Report by Voormolen to the Mayor of Rotterdam, 11 June 1895, 27-28.

61 S.A. Cole, Suspect Identities: A History of Fingerprinting and Criminal Identification (Cambridge, MA 2002) 37-43.

62 Fijnaut, Een staatsinstelling, 283; J. Jäger, Verfolgung durch Verwaltung: Internationales Verbrechen und internationale Polizeikooperation 1880-1933 (Konstanz 2006) 196-221.

63 F. Lignian, 'De anthropometrische signalementen volgens Alphonse Bertillon', Nederlands Tijdschrift voor Geneeskunde 38 (1894) 987-996.

64 Royal Decree, Staatsblad, 22 February 1896. Cf. 'Antropometrisch stelsel', Nieuws van de Dag, 3 January 1896.

65 'Het Bertillonage-stelsel', De Nederlandsche Politiegids 10, May 1895, no. 113; NL-HaNA, 2.09.05, 6488, no. 12, Exchange between the Minister of Justice, the Minister of Foreign Affairs and the Cabinet of the Queen Regent, 22 January 1896; no. 5, 12 February; no. 7, 15 February; no. 11, 19 February.

66 HTK 1897-1898, 2.IV.14, State budget for the Ministry of Justice for 1898, 11, as quoted in Fijnaut, Een staatsinstelling, 285.

67 J. Smeets, Marius van Houten: Marechaussee en diplomaat (Amsterdam 2011) 30-35; H.G. van de Bunt and E. Niemeijer (eds), Honderd jaar Rijksrecherche: Terugblik en toekomst (The Hague 1997).

68 Cf. H.C. Heering, Socialisten en justitie: Kroniek van een moeilijke relatie (Groningen 1994) 37.

69 SAR, 549, Autobiographical notes by W. Voormolen, undated.

70 Geheimes Staatsarchiv Preußischer Kulturbesitz (hereafter GStA PK), I. HA Rep. 77, Tit.1208, no.4, Bd. 2, no. I 1434, Prussian Minister of Foreign Affairs to the Prussian Minister of the Interior, Berlin, 19 March 1897.

71 GStA PK, I. HA Rep. 77, Tit. 1208, no.4, Bd. 2, no. I 1434, Von Windheim to the Prussian Minister of the Interior, Berlin, 29 March 1897.

72 GStA PK, I. HA Rep. 77, Tit.1208, no.4, Bd. 2, Protocol of the 'conference to discuss the introduction of Bertillon's system in the states of the German Empire', 1897.

73 'De nieuwe Broederschap', De Politiegids, April 1898, no. 148.

74 'Bijdragen. Broederschap Hoofd-Comm. en Comm. v. Politie' and 'Vereeniginsleeven', De Politiegids, November 1898, no. 155 and October 1899, no. 163.

75 A. de Burgh, Elizabeth, Empress of Austria: A Memoir (London 1899) 326-327.

76 Fraanje, 'Over internationale dollemannen', 13-29; cf. 'Buitenlandsch overzicht', Algemeen Handelsblad, 24 september 1898, evening edition; 'De moord op de keizerin van Oostenrijk', Rotterdamsch Nieuwsblad, 13 september 1898.

77 Le Soir is cited in 'Spißliches', Vorwärts, no. 219, 18 September 1898.

78 SAR, 63, 1548, no. 1898:3, Letter of Voormolen to the Rotterdam Director of Justice, 16 September 1898.

79 SAR, 63, 1548, no. 1898:3, Telegrams of Voormolen to the Attorney General of The Hague, 16 September 1898 at 20:15 and 20:45. 
80 SAR, 63, 1548, no. 1898:1, Letter of the Minister of Justice to Voormolen, The Hague, 22 September 1898.

81 J. Sweeney, At Scotland Yard: Being the Experiences during Twenty-Seven Years' Service of J. Sweeney, edited by Francis Richards (London 1904) 229232; R. Allason, The Branch: A History of the Metropolitan Police Special Branch 1883-1983 (London 1983) 14.

82 SAR, 63, 1548, no. 1898:1, Voormolen to the Department of Justice, 18 September 1898. Cf. Landesarchiv Berlin (hereafter LAB), A Pr.Br.Rep. 030, 8757.

83 LAB, A Pr.Br.Rep. 030, 8757, no. 1342, Secret letter Voormolen to Von Meerscheidt-Hüllessem, Rotterdam, 6 April 1899; no. 1342, Secret letter Von Windheim to Voormolen, Berlin, 27 May 1899.

84 SAR, 63, 1548, no. 1898:3, Secret letter of William Melville to Voormolen, London, 30 November 1898; Secret correspondence between Armand Cochefert and Voormolen, 7 December 1898, 1 January 1899, 3 and 9 January 1899.

85 F.H. Nichols, 'The anarchists in America', The Outlook 68 (10 August 1901) 859-863; G. Woodcock, Anarchism: A History of Libertarian Ideas and Movements (New York 1962) 315-351.

86 NL-HaNA, 2.09.05, 3004, no. 133, Letter of the Minister of Justice to Kist, Voormolen and Franken, 10 October 1898.

87 Ibid.

88 R.B. Jensen, 'The International Anti-Anarchist Conference of 1898 and the origins of Interpol', Journal of Contemporary History 16 (1981) 323-347; idem, The Battle against Anarchist Terrorism, ch. 5.

89 Vorwärts, 'Das Fiasco der Anarchistenkonferenz', 30 November 1898.

90 NL-HaNA, 2.09.05, 6453, no. 22, Instructions for Kist and Westenberg, drafted by the Minister of Justice and the Minister of Foreign Affairs.

91 Ibid.

92 NL-HaNA, 2.09.05, 6496, Conférence Internationale de Rome pour la défence sociale contre les anarchistes. 24 novembre -21 décembre 1898 (Rome 1898) 61-65.

93 The National Archives, Kew (hereafter TNA), FO 881, 7179; report of the second session of the administrative committee, Rome, 5 December 1898.

94 Ibid.

95 TNA, FO 881, 7179, Report of the third session of the administrative committee, Rome, 7 December 1898.

96 Ibid.

97 TNA, FO 881, 7179, no. 251, Report by Sir Howard Vincent on meetings held by Chiefs of Police attending Anti-Anarchist Conference, 24 December 1898.

98 See the Conference's final resolution in: NL-HaNA, 2.09.05, 6496, Conférence Internationale de Rome, 61-65.

99 Commissie-Kist, Verslag der commissie door den minister van Justitie benoemd om advies uit te brengen nopens de maatregelen welke tot verbetering van de politie kunnen strekken (The Hague 1901) ch. 1. Quoted in Fijnaut. Een staatsinstelling, 325.

100 J. Smeets, De geschiedenis van de Nederlandse politie: Verdeeldheid en eenheid in het rijkspolitieapparaat (Amsterdam 2007) 106. See also: NL-HaNA, 2.09.05, 3004, no. 113, Letter of the Minister of Justice to Kist, Franken and Voormolen, 6 October 1898; 'De Politie en 't Anarchisme', De Nederlandsche Politiegids, 15, September 1900, no. 177.

101 Herziening van het Wetboek van Strafrecht, Deel 1: Wetsontwerpen en toelichting (The Hague 1900) 91.

102 Ibid.; F. Domela Nieuwenhuis, 'Een Nederlandsche Anarchistenwet. Een geschenk der reactie aan de nieuwe eeuw', Vrije Socialist 4 (5 January 1901). 
103 HTK 1901-1902, II, 4th meeting on 24 September 1901.

104 NL-HaNA, 2.09.05, 6514, Letter of Voormolen to the Minister of Justice, 30 September 1903; HTK 1906/1907, 2.IV.14, State budget for the Ministry of Justice for 1907.

105 HTK 1904-1905, 36th meeting on 20 December 1904, 219; indeed, the Amsterdam police had photographed La Tribune Russe in accordance with their Russian colleagues, NL-HaNA, 2.09.05, 6646, no. 66, Procurer-General of Amsterdam to the Minister of Justice, 18 August 1904.

106 NL-HaNA, 2.09.05, 6646; Report by the Amsterdam Procurer-General, 26 August 1904. Despite the attendance of Rataev, there were no Russian agents in the Netherlands on a permanent basis: see Hoover Institution Archives, Stanford (HIA), Russia. Departament politsii. Zaganichnaia agentura (Paris), Vf, 2, r.73, Relations with police of other countries, Holland 1894-1911.

107 W.M. Klem, 'Dynamiet onder de Dam: De rol van de anarchistische samenzwering bij de institutionalisering en professionalisering van Nederlands veiligheidsbeleid, 1881-1914' (unpublished MA thesis, Leiden University 2013).

108 Zuckerman, The Tsarist Secret Police Abroad, 60.

109 M. Deflem, Policing World Society: Historical Foundations of International Police Cooperation (Oxford 2002). See also: Jäger, Verfolgung durch Verwaltung; Jensen, The Battle against Anarchist Terrorism; P. Knepper, The Invention of International Crime: A Global Issue in the Making, 1881-1914 (London 2010). 